\title{
Studies on the Constituents of Polygala japonica Houtr. I. Structures of Polygalasaponins I-X
}

\author{
Dongming Zhang, Toshio MiYase, ${ }^{*}$ Masanori Kuroyanagi, Kaoru Umehara, and \\ Akira UENO
}

School of Pharmaceutical Sciences, University of Shizuoka, 52-1, Yada, Shizuoka 422, Japan.

Received July 18, 1994; accepted September 27, 1994

\begin{abstract}
Ten new oleanane-type saponins, polygalasaponins $\mathrm{I}-\mathrm{X}$, along with two known saponins, bayogenin-3- $O-\beta$-Dglucopyranoside and lobatoside B were isolated from the aerial part of Polygala japonica Houtr. The structures of these compounds were established on the basis of spectroscopic and chemical evidence.
\end{abstract}

Keywords Polygala japonica; Polygalaceae; polygalasaponin; oleanane-type saponin; bayogenin

Polygala japonica Houtr. is widely distributed in southern China, and is used as an expectorant, an anti-inflammatory agent for pharyngitis and an antibacterial agent. ${ }^{1)}$ Fang and Yin $^{2,3)}$ reported the isolation and structure determination of three saponins whose aglycone was $2 \alpha, 3 \alpha, 24$-trihydroxyolean-12-en-28-oic acid from this plant. During the course of further investigation, we obtained ten new saponins whose aglycone was bayogenin, designated as polygalasaponins I-X (1-10). This paper deals with the isolation and structural elucidation of these saponins.

A 70\% aqueous ethanol extract of the aerial part of $P$. japonica Houtr. was passed through a porous polymer gel Mitsubishi Diaion HP-20 column and the adsorbed materials were eluted with $50 \%$ aqueous methanol and methanol, successively. The methanol eluate was chromatographed on silica gel and octadecyl silica (ODS) columns, followed by repeated semi-preparative HPLC on a reversed phase column [ODS, phenylalkyl (PhA)]. We isolated twelve saponins, the structures of ten of these were established and the two other were identified as bayogenin3-O- $\beta$-D-glucopyranoside (11) and lobatoside B (12) by comparison of the spectral data with reported data. ${ }^{4,5)}$ New saponins $(\mathbf{1}-\mathbf{1 0})$ afforded bayogenin $(\mathbf{1 3})$ as an aglycone on acid hydrolysis.

Polygalasaponin I (1) revealed a $[\mathrm{M}+\mathrm{Na}]^{+}$ion peak at $m / z 835$ in the FAB-MS and elemental analysis data was consistent with $\mathrm{C}_{42} \mathrm{H}_{68} \mathrm{O}_{15}$. On acid hydrolysis, 1 afforded D-glucose as a sugar moiety. The ${ }^{1} \mathrm{H}$-NMR spectrum of
1 showed two anomeric proton signals at $\delta 5.12(\mathrm{~d}$, $J=8 \mathrm{~Hz})$ and $6.29(\mathrm{~d}, J=8 \mathrm{~Hz})$. Sugar proton signals (Tables I, II) were assigned by detailed proton spin decoupling experiment, ${ }^{1} \mathrm{H}-{ }^{1} \mathrm{H}$ correlation spectroscopy (COSY) and ${ }^{13} \mathrm{C}-{ }^{1} \mathrm{H}$ COSY spectra, while the ${ }^{13} \mathrm{C}-\mathrm{NMR}$ spectrum of 1 exhibited two anomeric carbon signals at $\delta 95.8$ and 105.7. Comparing the ${ }^{13} \mathrm{C}-\mathrm{NMR}$ spectrum of 1 with that of bayogenin (13), glycosylation shifts at C-2 $(-1.0 \mathrm{ppm}), \mathrm{C}-3(+9.9 \mathrm{ppm})$ and C-28 $(-3.7 \mathrm{ppm})$ of the aglycone indicated that 1 was a 3,28-bisdesmoside of bayogenin (13). The anomeric configurations of two glucoses were both determined to be $\beta$ from the $J$ values of their anomeric proton signals. Therefore, polygalasaponin I was characterized as 3-O- $\beta$-D-glucopyranosyl bayogenin $28-O-\beta$-D-glucopyranosyl ester.

Polygalasaponin II (2) showed a $[\mathrm{M}+\mathrm{Na}]^{+}$ion peak at $m / z 982$ in the FAB-MS. Combined with the result of elemental analysis, its molecular formula was deduced as $\mathrm{C}_{48} \mathrm{H}_{78} \mathrm{O}_{19}$. Upon acid hydrolysis, 2 gave D-glucose and L-rhamnose as a sugar moiety. The ${ }^{1} \mathrm{H}-\mathrm{NMR}$ spectrum of 2 showed three anomeric proton signals at $\delta 5.11(\mathrm{~d}$, $J=8 \mathrm{~Hz}), 6.17(\mathrm{~d}, J=8 \mathrm{~Hz})$ and $6.53(\mathrm{br} \mathrm{s})$. The ${ }^{13} \mathrm{C}-\mathrm{NMR}$ spectrum of 2 showed three anomeric carbon signals at $\delta 94.9,101.5$ and 105.7. Glycosylation shifts in the aglycone moiety indicated that 2 was a 3,28-bisdesmoside. Since the anomeric carbon signal ( $\delta 94.7)$ due to glucose showed an ester-type glycoside linkage, one glucose was found to be linked at C-28 of bayogenin. Nuclear Overhauser effects (NOE)s were observed at $\mathrm{H}-3[\delta 4.27$

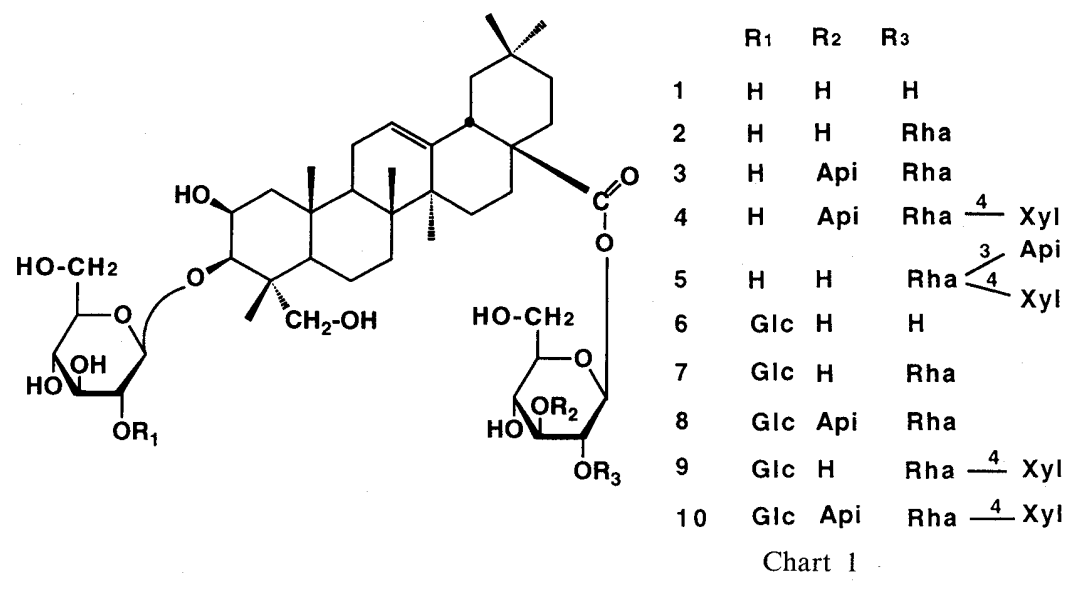

(C) 1995 Pharmaceutical Societv of Janan

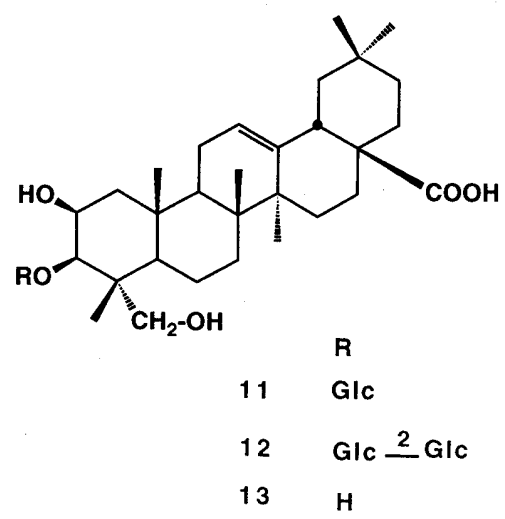


TABLE I. ${ }^{1}$ H-NMR Spectral Data of Compounds $\mathbf{1}-12$ in Pyridine- $d_{5}$

\begin{tabular}{|c|c|c|c|c|c|}
\hline & $\mathbf{1}$ & 2 & 3 & 4 & 5 \\
\hline \multicolumn{6}{|l|}{ Aglycone } \\
\hline 2 & $4.78(1 \mathrm{H}, \mathrm{m})$ & $4.77(1 \mathrm{H}, \mathrm{m})$ & $4.78(1 \mathrm{H}, \mathrm{m})$ & $4.79(1 \mathrm{H}, \mathrm{m})$ & $4.78(1 \mathrm{H}, \mathrm{m})$ \\
\hline 12 & $5.44(1 \mathrm{H}, \mathrm{t}$-like $)$ & $5.47(1 \mathrm{H}, \mathrm{t}$-like $)$ & $5.47(1 \mathrm{H}, \mathrm{t}$-like $)$ & $5.47(1 \mathrm{H}, \mathrm{t}$-like $)$ & $5.45(1 \mathrm{H}, \mathrm{t}$-like $)$ \\
\hline 18 & $3.18(1 \mathrm{H}, \mathrm{dd}, J=14,4 \mathrm{~Hz})$ & $3.11(1 \mathrm{H}, \mathrm{dd}, J=14,4 \mathrm{~Hz})$ & $3.10(1 \mathrm{H}, \mathrm{dd}, J=14,4 \mathrm{~Hz})$ & $3.10(1 \mathrm{H}, \mathrm{dd}, J=14,4 \mathrm{~Hz})$ & $3.11(1 \mathrm{H}, \mathrm{dd}, J=14,4 \mathrm{~Hz})$ \\
\hline \multirow[t]{2}{*}{23} & $3.66(1 \mathrm{H}, \mathrm{d}, J=11 \mathrm{~Hz})$ & $3.60(1 \mathrm{H}, \mathrm{d}, J=11 \mathrm{~Hz})$ & $3.61(1 \mathrm{H}, \mathrm{d}, J=11 \mathrm{~Hz})$ & $3.74(1 \mathrm{H}, \mathrm{d}, J=11 \mathrm{~Hz})$ & $3.75(1 \mathrm{H}, \mathrm{d}, J=11 \mathrm{~Hz})$ \\
\hline & $4.30(1 \mathrm{H}, \mathrm{d}, J=11 \mathrm{~Hz})$ & $4.30(1 \mathrm{H}, \mathrm{d}, J=11 \mathrm{~Hz})$ & $4.31(1 \mathrm{H}, \mathrm{d}, J=11 \mathrm{~Hz})$ & $4.36(1 \mathrm{H}, \mathrm{d}, J=11 \mathrm{~Hz})$ & $4.32(1 \mathrm{H}, \mathrm{d}, J=11 \mathrm{~Hz})$ \\
\hline 25 & $1.56(3 \mathrm{H}, \mathrm{s})$ & $1.56(3 \mathrm{H}, \mathrm{s})$ & $1.58(3 \mathrm{H}, \mathrm{s})$ & $1.56(3 \mathrm{H}, \mathrm{s})$ & $1.56(3 \mathrm{H}, \mathrm{s})$ \\
\hline 26 & $1.16(3 \mathrm{H}, \mathrm{s})$ & $1.15(3 \mathrm{H}, \mathrm{s})$ & $1.15(3 \mathrm{H}, \mathrm{s})$ & $1.16(3 \mathrm{H}, \mathrm{s})$ & $1.17(3 \mathrm{H}, \mathrm{s})$ \\
\hline 27 & $1.22(3 \mathrm{H}, \mathrm{s})$ & $1.23(3 \mathrm{H}, \mathrm{s})$ & $1.22(3 \mathrm{H}, \mathrm{s})$ & $1.21(3 \mathrm{H}, \mathrm{s})$ & $1.23(3 \mathrm{H}, \mathrm{s})$ \\
\hline 29 & $0.89(3 \mathrm{H}, \mathrm{s})$ & $0.86(3 \mathrm{H}, \mathrm{s})$ & $0.86(3 \mathrm{H}, \mathrm{s})$ & $0.84(3 \mathrm{H}, \mathrm{s})$ & $0.88(3 \mathrm{H}, \mathrm{s})$ \\
\hline 30 & $0.88(3 \mathrm{H}, \mathrm{s})$ & $0.81(3 \mathrm{H}, \mathrm{s})$ & $0.83(3 \mathrm{H}, \mathrm{s})$ & $0.82(3 \mathrm{H}, \mathrm{s})$ & $0.85(3 \mathrm{H}, \mathrm{s})$ \\
\hline \multicolumn{6}{|l|}{ C-3 sugar } \\
\hline Glc-1 linner & $5.12(1 \mathrm{H}, \mathrm{d}, J=8 \mathrm{~Hz})$ & $5.11(1 \mathrm{H}, \mathrm{d}, J=8 \mathrm{~Hz})$ & $5.13(1 \mathrm{H}, \mathrm{d}, J=8 \mathrm{~Hz})$ & $5.17(1 \mathrm{H}, \mathrm{d}, J=8 \mathrm{~Hz})$ & $5.13(1 \mathrm{H}, \mathrm{d}, J=8 \mathrm{~Hz})$ \\
\hline 2 & $3.98(1 \mathrm{H}, \mathrm{t}, J=8.5 \mathrm{~Hz})$ & $4.00(1 \mathrm{H}, \mathrm{t}, J=8.5 \mathrm{~Hz})$ & $4.01(1 \mathrm{H}, \mathrm{t}, J=8.5 \mathrm{~Hz})$ & $4.03(1 \mathrm{H}, \mathrm{t}, J=8.5 \mathrm{~Hz})$ & $4.01(1 \mathrm{H}, \mathrm{t}, J=8.5 \mathrm{~Hz})$ \\
\hline 3 & $4.12(1 \mathrm{H}, \mathrm{t}, J=8.5 \mathrm{~Hz})$ & $4.13(1 \mathrm{H}, \mathrm{t}, J=8.5 \mathrm{~Hz})$ & $4.14(1 \mathrm{H}, \mathrm{t}, J=8.5 \mathrm{~Hz})$ & $4.18(1 \mathrm{H}, \mathrm{t}, J=8.5 \mathrm{~Hz})$ & $4.14(1 \mathrm{H}, \mathrm{t}, J=8.5 \mathrm{~Hz})$ \\
\hline 5 & $3.88(1 \mathrm{H}, \mathrm{m})$ & $3.88(1 \mathrm{H}, \mathrm{m})$ & $3.88(1 \mathrm{H}, \mathrm{m})$ & $3.91(1 \mathrm{H}, \mathrm{m})$ & $3.88(1 \mathrm{H}, \mathrm{m})$ \\
\hline \multirow[t]{3}{*}{6} & $4.29(1 \mathrm{H}, \mathrm{dd}, J=12,5 \mathrm{~Hz})$ & $4.30^{a)}$ & $4.31^{a)}$ & $4.36^{a)}$ & $4.32^{a)}$ \\
\hline & $4.43(1 \mathrm{H}, \mathrm{brd}, J=12 \mathrm{~Hz})$ & $4.43^{a)}$ & $4.44(1 \mathrm{H}, \mathrm{dd}, J=12,2 \mathrm{~Hz})$ & $4.42^{a)}$ & $4.44(1 \mathrm{H}, \mathrm{dd}, J=12,2 \mathrm{~Hz})$ \\
\hline & 6 & 7 & 8 & 9 & 10 \\
\hline \multicolumn{6}{|l|}{ Aglycone } \\
\hline 2 & $4.71(1 \mathrm{H}, \mathrm{m})$ & $4.72(1 \mathrm{H}, \mathrm{m})$ & $4.73(1 \mathrm{H}, \mathrm{m})$ & $4.73(1 \mathrm{H}, \mathrm{m})$ & $4.73(1 \mathrm{H}, \mathrm{m})$ \\
\hline 3 & $4.15(1 \mathrm{H}, \mathrm{d}, J=3 \mathrm{~Hz})$ & $4.13(1 \mathrm{H}, \mathrm{d}, J=3 \mathrm{~Hz})$ & $4.14(1 \mathrm{H}, \mathrm{d}, J=3 \mathrm{~Hz})$ & $4.16(1 \mathrm{H}, \mathrm{d}, J=3 \mathrm{~Hz})$ & $4.15(1 \mathrm{H}, \mathrm{d}, J=3 \mathrm{~Hz})$ \\
\hline 12 & $5.41(1 \mathrm{H}, \mathrm{t}$-like $)$ & $5.46(1 \mathrm{H}, \mathrm{t}-\mathrm{like})$ & $5.47(1 \mathrm{H}, \mathrm{t}-\mathrm{like})$ & $5.45(1 \mathrm{H}, \mathrm{t}$-like $)$ & $5.45(1 \mathrm{H}, \mathrm{t}-\mathrm{like})$ \\
\hline 18 & $3.16(1 \mathrm{H}, \mathrm{dd}, J=14,4 \mathrm{~Hz})$ & $3.10(1 \mathrm{H}, \mathrm{dd}, J=14,4 \mathrm{~Hz})$ & $3.10(1 \mathrm{H}, \mathrm{dd}, J=14,4 \mathrm{~Hz})$ & $3.10(1 \mathrm{H}, \mathrm{dd}, J=14,4 \mathrm{~Hz})$ & $3.09(1 \mathrm{H}, \mathrm{dd}, J=14,4 \mathrm{~Hz})$ \\
\hline \multirow[t]{2}{*}{23} & $3.69(1 \mathrm{H}, \mathrm{d}, J=11 \mathrm{~Hz})$ & $3.62(1 \mathrm{H}, \mathrm{d}, J=11 \mathrm{~Hz})$ & $3.65(1 \mathrm{H}, \mathrm{d}, J=11 \mathrm{~Hz})$ & $3.75(1 \mathrm{H}, \mathrm{d}, J=11 \mathrm{~Hz})$ & $3.75(1 \mathrm{H}, \mathrm{d}, J=11 \mathrm{~Hz})$ \\
\hline & $4.31(1 \mathrm{H}, \mathrm{d}, J=11 \mathrm{~Hz})$ & $4.37(1 \mathrm{H}, \mathrm{d}, J=11 \mathrm{~Hz})$ & $4.31(1 \mathrm{H}, \mathrm{d}, J=11 \mathrm{~Hz})$ & $4.29(1 \mathrm{H}, \mathrm{d}, J=11 \mathrm{~Hz})$ & $4.30(1 \mathrm{H}, \mathrm{d}, J=11 \mathrm{~Hz})$ \\
\hline 24 & $1.40(3 \mathrm{H}, \mathrm{s})$ & $1.37(3 \mathrm{H}, \mathrm{s})$ & $1.39(3 \mathrm{H}, \mathrm{s})$ & $1.38(3 \mathrm{H}, \mathrm{s})$ & $1.38(3 \mathrm{H}, \mathrm{s})$ \\
\hline 25 & $1.53(3 \mathrm{H}, \mathrm{s})$ & $1.55(3 \mathrm{H}, \mathrm{s})$ & $1.57(3 \mathrm{H}, \mathrm{s})$ & $1.53(3 \mathrm{H}, \mathrm{s})$ & $1.53(3 \mathrm{H}, \mathrm{s})$ \\
\hline 26 & $1.14(3 \mathrm{H}, \mathrm{s})$ & $1.14(3 \mathrm{H}, \mathrm{s})$ & $1.15(3 \mathrm{H}, \mathrm{s})$ & $1.16(3 \mathrm{H}, \mathrm{s})$ & $1.14(3 \mathrm{H}, \mathrm{s})$ \\
\hline 27 & $1.18(3 \mathrm{H}, \mathrm{s})$ & $1.21(3 \mathrm{H}, \mathrm{s})$ & $1.20(3 \mathrm{H}, \mathrm{s})$ & $1.21(3 \mathrm{H}, \mathrm{s})$ & $1.20(3 \mathrm{H}, \mathrm{s})$ \\
\hline Glc-1 inner & $5.06(1 \mathrm{H}, \mathrm{d}, J=8 \mathrm{~Hz})$ & $5.06(1 \mathrm{H}, \mathrm{d}, J=8 \mathrm{~Hz})$ & $5.07(1 \mathrm{H}, \mathrm{d}, J=8 \mathrm{~Hz})$ & $5.07(1 \mathrm{H}, \mathrm{d}, J=8 \mathrm{~Hz})$ & $5.08(1 \mathrm{H}, \mathrm{d}, J=8 \mathrm{~Hz})$ \\
\hline 2 & $4.08(1 \mathrm{H}, \mathrm{t}, J=8.5 \mathrm{~Hz})$ & $4.08(1 \mathrm{H}, \mathrm{t}, J=8.5 \mathrm{~Hz})$ & $4.10(1 \mathrm{H}, \mathrm{t}, J=8.5 \mathrm{~Hz})$ & $4.09(1 \mathrm{H}, \mathrm{t}, J=8.5 \mathrm{~Hz})$ & $4.09(1 \mathrm{H}, \mathrm{t}, J=8.5 \mathrm{~Hz})$ \\
\hline 3 & $4.19(1 \mathrm{H}, t, J=9 \mathrm{~Hz})$ & $4.19(1 \mathrm{H}, \mathrm{t}, J=9 \mathrm{~Hz})$ & $4.21(1 \mathrm{H}, \mathrm{t}, J=9 \mathrm{~Hz})$ & $4.21(1 \mathrm{H}, \mathrm{t}, J=9 \mathrm{~Hz})$ & $4.22(1 \mathrm{H}, \mathrm{t}, J=9 \mathrm{~Hz})$ \\
\hline 4 & $4.10(1 \mathrm{H}, \mathrm{t}, J=9 \mathrm{~Hz})$ & $4.10(1 \mathrm{H}, t, J=9 \mathrm{~Hz})$ & $4.13(1 \mathrm{H}, \mathrm{t}, J=9 \mathrm{~Hz})$ & $4.12(1 \mathrm{H}, \mathrm{t}, J=9 \mathrm{~Hz})$ & $4.12(1 \mathrm{H}, \mathrm{t}, J=9 \mathrm{~Hz})$ \\
\hline 5 & $3.80(1 \mathrm{H}, \mathrm{m})$ & $3.81(1 \mathrm{H}, \mathrm{m})$ & $3.82(1 \mathrm{H}, \mathrm{m})$ & $3.82(1 \mathrm{H}, \mathrm{m})$ & $3.82(1 \mathrm{H}, \mathrm{m})$ \\
\hline \multirow[t]{2}{*}{6} & $4.23^{a)}$ & $4.23(1 \mathrm{H}, \mathrm{dd}, J=12,5 \mathrm{~Hz})$ & $4.23^{a)}$ & $4.25^{a)}$ & $4.23^{a)}$ \\
\hline & $4.39^{a)}$ & $4.41^{a)}$ & $4.39^{a)}$ & $4.41(1 \mathrm{H}, \mathrm{dd}, J=12,2 \mathrm{~Hz})$ & $4.41(1 \mathrm{H}, \mathrm{dd}, J=12,2 \mathrm{~Hz})$ \\
\hline Glc-1 terminal & $5.32(1 \mathrm{H}, \mathrm{d}, J=8 \mathrm{~Hz})$ & $5.32(1 \mathrm{H}, \mathrm{d}, J=8 \mathrm{~Hz})$ & $5.34(1 \mathrm{H}, \mathrm{d}, J=8 \mathrm{~Hz})$ & $5.33(1 \mathrm{H}, \mathrm{d}, J=8 \mathrm{~Hz})$ & $5.33(1 \mathrm{H}, \mathrm{d}, J=8 \mathrm{~Hz})$ \\
\hline 2 & $4.06(1 \mathrm{H}, \mathrm{t}, J=8.5 \mathrm{~Hz})$ & $4.07(1 \mathrm{H}, \mathrm{t}, J=8.5 \mathrm{~Hz})$ & $4.09^{a)}$ & $4.08(1 \mathrm{H}, \mathrm{t}, J=8.5 \mathrm{~Hz})$ & $4.08^{a)}$ \\
\hline 3 & $4.17(1 \mathrm{H}, \mathrm{t}, J=9 \mathrm{~Hz})$ & $4.17(1 \mathrm{H}, \mathrm{t}, J=9 \mathrm{~Hz})$ & $4.19(1 \mathrm{H}, \mathrm{t}, J=9 \mathrm{~Hz})$ & $4.18(1 \mathrm{H}, \mathrm{t}, J=9 \mathrm{~Hz})$ & $4.20(1 \mathrm{H}, \mathrm{t}, J=9 \mathrm{~Hz})$ \\
\hline 4 & $4.19(1 \mathrm{H}, \mathrm{t}, J=9 \mathrm{~Hz})$ & $4.24(1 \mathrm{H}, \mathrm{t}, J=9 \mathrm{~Hz})$ & $4.23^{a)}$ & $4.22(1 \mathrm{H}, \mathrm{t}, J=9 \mathrm{~Hz})$ & $4.23^{a)}$ \\
\hline 5 & $3.89(1 \mathrm{H}, \mathrm{m})$ & $3.90(1 \mathrm{H}, \mathrm{m})$ & $3.91(1 \mathrm{H}, \mathrm{m})$ & $3.90(1 \mathrm{H}, \mathrm{m})$ & $3.91(1 \mathrm{H}, \mathrm{m})$ \\
\hline \multirow[t]{2}{*}{6} & $4.37^{a)}$ & $4.39^{a)}$ & $4.39^{a)}$ & $4.38^{a)}$ & $4.39^{a)}$ \\
\hline & $4.47(1 \mathrm{H}, \mathrm{dd}, J=12,2 \mathrm{~Hz})$ & $4.48(1 \mathrm{H}, \mathrm{dd}, J=12,2 \mathrm{~Hz})$ & $4.50(1 \mathrm{H}, \mathrm{dd}, J=12,2 \mathrm{~Hz})$ & $4.50(1 \mathrm{H}, \mathrm{dd}, J=12,2 \mathrm{~Hz})$ & $4.50(1 \mathrm{H}, \mathrm{dd}, J=12,2 \mathrm{~Hz})$ \\
\hline
\end{tabular}

Recorded at $500 \mathrm{MHz}$ a) Overlapping with other signals.

$(\mathrm{d}, J=3 \mathrm{~Hz})]$ of the aglycone moiety on irradiation at $\mathrm{H}-1$ $[\delta 5.11(\mathrm{~d}, J=8 \mathrm{~Hz})]$ of glucose and at $\mathrm{H}-2(\delta 4.43)$ of glucose to be linked at C-28 of bayogenin on irradiation at $\mathrm{H}-1[\delta 6.53$ (brs) $]$ of rhamnose in the difference NOE spectrum. Based upon the above evidence, the structure of polygalasaponin II was elucidated as $3-O-\beta$-D-glucopyranosyl bayogenin $28-O-[\alpha-\mathrm{L}-\mathrm{rhamnopyranosyl}-(1 \rightarrow$ 2)- $\beta$-D-glucopyranosyl] ester.

Polygalasaponin III (3), $\mathrm{C}_{53} \mathrm{H}_{86} \mathrm{O}_{23}$, showed four anomeric proton signals at $\delta 5.13(\mathrm{~d}, J=8 \mathrm{~Hz}), 5.81(\mathrm{~d}$, $J=3 \mathrm{~Hz}), 6.03(\mathrm{brs})$ and $6.18(\mathrm{~d}, J=7 \mathrm{~Hz})$ in the ${ }^{1} \mathrm{H}-\mathrm{NMR}$ spectrum. On acid hydrolysis, 3 afforded D-glucose, Lrhamnose and D-apiose as a sugar moiety. The NOE experiment irradiating at each anomeric proton signal and the hetero nuclear multiple bond coherence (HMBC) spectrum showed the connections of individual monosaccharides (Chart 2). So, the structure of polygalasaponin III was determined to be $3-O-\beta$-D-glucopyranosyl bayo-

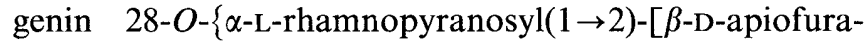
$\operatorname{nosyl}(1 \rightarrow 3)]-\beta$-D-glucopyranosyl $\}$ ester.

Polygalasaponin IV (4) revealed a $[\mathrm{M}+\mathrm{Na}]^{+}$ion peak at $m / z 1246$ in the FAB-MS and elemental analysis data was consistent with $\mathrm{C}_{58} \mathrm{H}_{94} \mathrm{O}_{27}$. Compound 4 gave D-glucose, D-xylose, D-apiose and L-rhamnose as a sugar moiety on acid hydrolysis. In the NMR spectra, 4 exhibited five anomeric proton and carbon signals at $\delta 5.08(\mathrm{~d}$, $J=7 \mathrm{~Hz}), 5.17(\mathrm{~d}, J=8 \mathrm{~Hz}), 5.82(\mathrm{~d}, J=3 \mathrm{~Hz}), 6.03$ (br s), $6.23(\mathrm{~d}, J=7 \mathrm{~Hz}) ; 94.1,101.4,105.8,107.5,111.0$. The sugar linkages were determined by means of NOE with irradiation at each anomeric proton signal. Therefore, the 
TABle II. ${ }^{1} \mathrm{H}-\mathrm{NMR}$ Spectral Data of Compounds $\mathbf{1}-\mathbf{1 0}$ in Pyridine- $d_{5}$

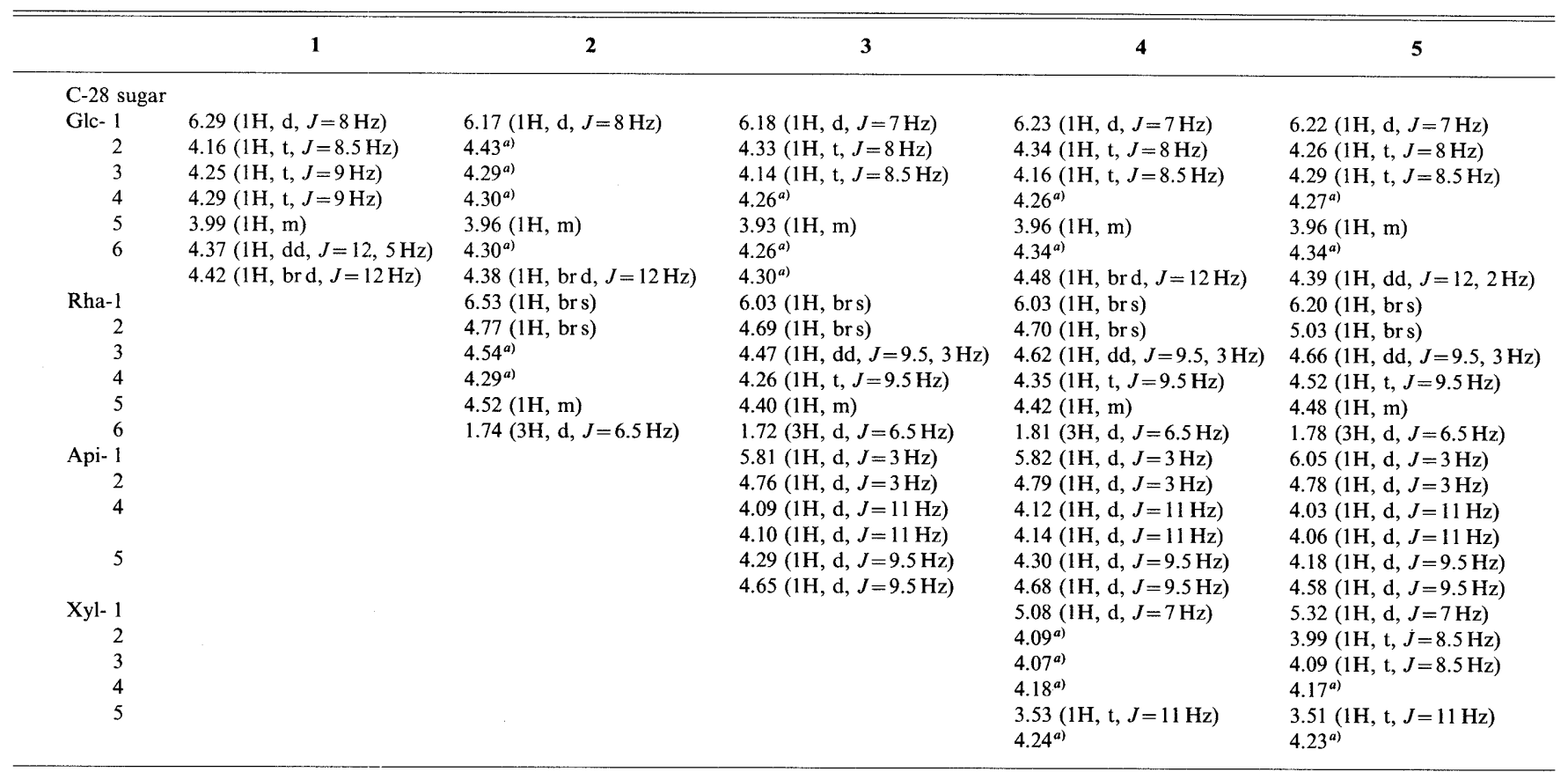

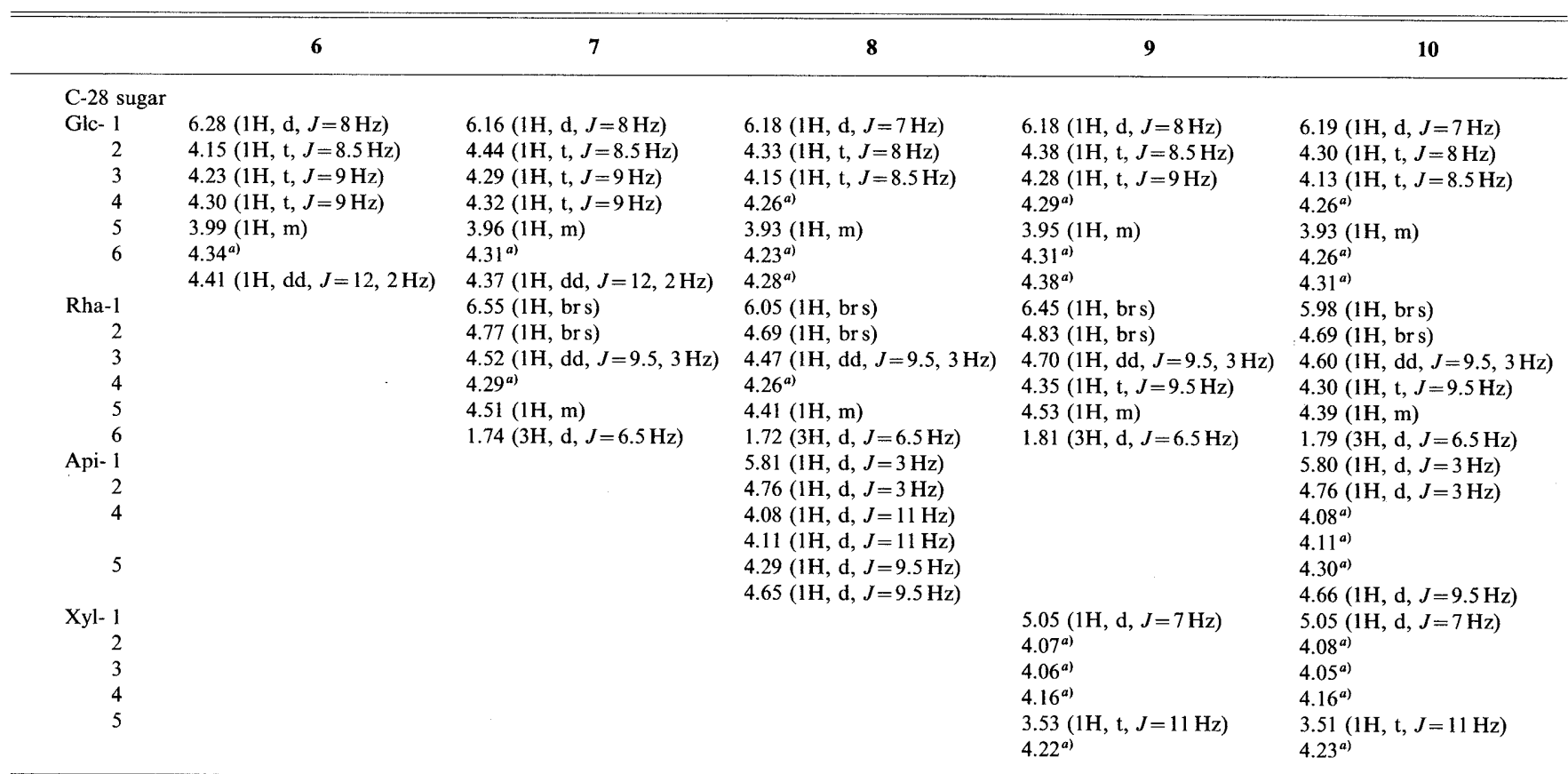

Recorded at $500 \mathrm{MHz}$. a) Overlapping with other signals.

structure of polygalasaponin IV was elucidated as 3-O$\beta$-D-glucopyranosyl bayogenin $28-O-\{\beta$-D-xylopyranosyl$(1 \rightarrow 4)-\alpha$-L-rhamnopyranosyl $(1 \rightarrow 2)$-[ $[\beta$-D-apiofuranosyl$(1 \rightarrow 3)]$ - $\beta$-D-glucopyranosyl $\}$ ester.

Polygalasaponin V (5) afforded D-glucose, D-xylose, D-apiose and L-rhamnose on acid hydrolysis. Its molecular formula is $\mathrm{C}_{58} \mathrm{H}_{94} \mathrm{O}_{27}$ from the FAB-MS and elemental analysis. The ${ }^{1} \mathrm{H}$-NMR spectrum of $\mathbf{5}$ disclosed five anomeric proton signals at $\delta 5.13(\mathrm{~d}, J=8 \mathrm{~Hz}), 5.32$ $(\mathrm{d}, J=7 \mathrm{~Hz}), 6.05(\mathrm{~d}, J=3 \mathrm{~Hz}), 6.20(\mathrm{br} \mathrm{s})$ and $6.22(\mathrm{~d}$, $J=7 \mathrm{~Hz}$ ). The binding sites of each monosaccharide were determined by the NOE method. When the signals at $\delta 5.13$ (H-1 of glucose), 5.32 (H-1 of xylose), 6.05 (H-1 of apiose) and 6.20 (H-1 of rhamnose) were irradiated, NOEs were observed at signals due to $\mathrm{H}-3$ of an aglycone, $\mathrm{H}-4$ of rhamnose, $\mathrm{H}-3$ of rhamnose and $\mathrm{H}-2$ of ester-linked glucose, respectively. From these data, the structure of polygalasaponin $\mathrm{V}$ was determined to be $3-O-\beta$-Dglucopyranosyl bayogenin $28-O-\{\beta$-D-xylopyranosyl $(1 \rightarrow$ 4)- $[\beta$-D-apiofuranosyl $(1 \rightarrow 3)]-\alpha$-L-rhamnopyranosyl $(1 \rightarrow$ 2)- $\beta$-D-glucopyranosyl\} ester.

Polygalasaponin VI (6) showed a $[\mathrm{M}+\mathrm{Na}]^{+}$ion peak at $\mathrm{m} / \mathrm{z} 997$ in the FAB-MS and had a molecular formula $\mathrm{C}_{48} \mathrm{H}_{78} \mathrm{O}_{20}$ by elemental analysis. On acid hydrolysis, 6 afforded D-glucose. In the ${ }^{1} \mathrm{H}$-NMR spectrum, 6 showed three anomeric proton signals at $\delta 5.06(\mathrm{~d}, J=8 \mathrm{~Hz}), 5.32$ 


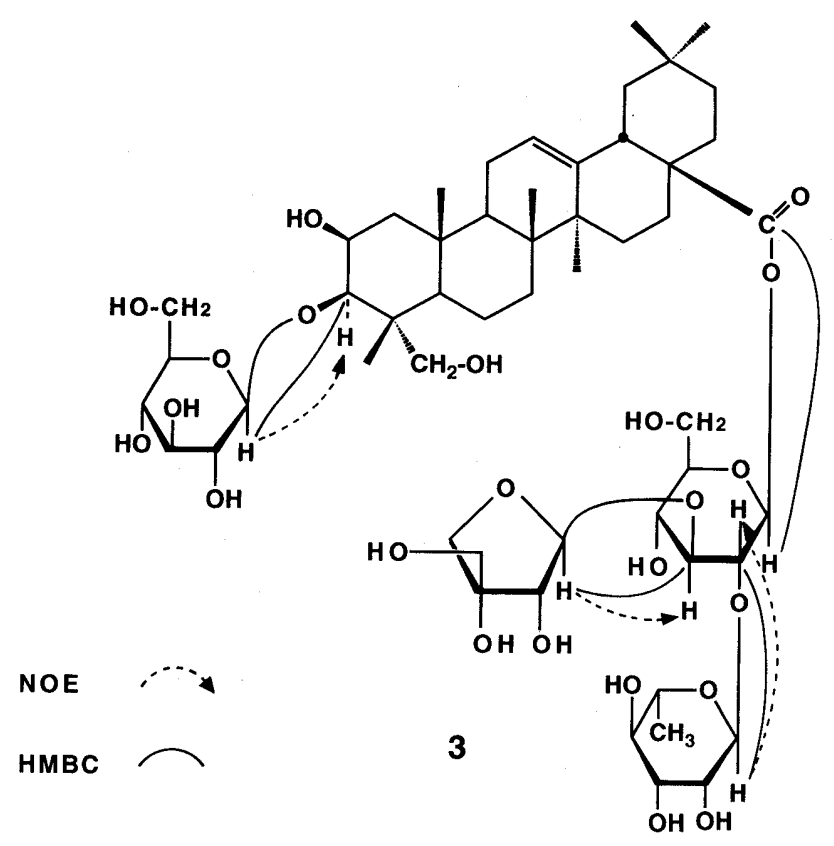

Chart 2

(d, $J=8 \mathrm{~Hz}$ ) and $6.28(\mathrm{~d}, J=8 \mathrm{~Hz})$. The ${ }^{13} \mathrm{C}-\mathrm{NMR}$ spectrum of 6 exhibited three anomeric carbon signals, and glycosylation shifts at C-2 (-1.3 ppm), C-3 (+9.9 ppm) and C-28 ( $-3.7 \mathrm{ppm})$ of aglycone indicated that 6 was a 3,28-bisdesmoside. NOEs were observed at $\mathrm{H}-3$ $(\delta 4.15)$ of the aglycone and $\mathrm{H}-2[\delta 4.08(\mathrm{t}, J=8.5 \mathrm{~Hz})]$ of glucose attached at $\mathrm{C}-3$ of the aglycone, with irradiation at anomeric proton signals $\delta 5.06(\mathrm{~d}, J=8 \mathrm{~Hz})$ and $5.32(\mathrm{~d}$, $J=8 \mathrm{~Hz}$ ), respectively. From these results, the structure of polygalasaponin VI was elucidated as $3-O-[\beta-\mathrm{D}-$ glucopyranosyl $(1 \rightarrow 2)$ - $\beta$-D-glucopyranosyl]bayogenin 28 $O$ - $\beta$-D-glucopyranosyl ester.

The FAB-MS and elemental analysis of polygalasaponin VII (7) gave the molecular formula $\mathrm{C}_{54} \mathrm{H}_{88} \mathrm{O}_{24}$. Compound 7 showed the presence of four anomeric proton and carbon signals $[\delta 5.06(\mathrm{~d}, J=8 \mathrm{~Hz}), 5.32(\mathrm{~d}, J=8 \mathrm{~Hz})$, $6.16(\mathrm{~d}, J=8 \mathrm{~Hz}), 6.55$ (br s); 94.9, 101.5, 103.0, 105.9] in the NMR spectra. On acid hydrolysis, 7 gave D-glucose and L-rhamnose as a sugar moiety. The sugar linkages were decided by the NOE method. When the signals at $\delta 5.06,5.32$ (H-1 of each glucose) and 6.55 (H-1 of rhamnose) were irradiated, NOEs were observed at signals due to $\mathrm{H}-3$ of bayogenin, $\mathrm{H}-2$ of glucose attached at C-3 of bayogenin and $\mathrm{H}-2$ of glucose linked at C-28 of bayogenin, respectively. The structure of polygalasaponin VII was thus characterized as 3-O-[ $\beta$-D-glucopyranosyl $(1 \rightarrow 2)$ $\beta$-D-glucopyranosyl]bayogenin 28- $O$-[ $\alpha$-L-rhamnopyranosyl $(1 \rightarrow 2)$ - $\beta$-D-glucopyranosyl] ester.

Polygalasaponin VIII (8) revealed a $[\mathrm{M}+\mathrm{Na}]^{+}$ion peak at $m / z 1276$ in the FAB-MS and elemental analysis data was consistent with $\mathrm{C}_{59} \mathrm{H}_{96} \mathrm{O}_{28}$. On acid hydrolysis, 8 afforded D-glucose, L-rhamnose and D-apiose as a sugar moiety. In the NMR spectra, 8 exhibited five anomeric proton and carbon signals at $\delta 5.07(\mathrm{~d}, J=8 \mathrm{~Hz}), 5.34(\mathrm{~d}$, $J=8 \mathrm{~Hz}$ ), 5.81 (d, $J=3 \mathrm{~Hz}), 6.05$ (br s), 6.18 (d, $J=7 \mathrm{~Hz}$; $94.3,101.7,102.9,105.9,111.2$, indicating that 8 was a 3,28-bisdesmoside. The ${ }^{1} \mathrm{H}$ - and ${ }^{13} \mathrm{C}-\mathrm{NMR}$ chemical shifts of $\mathbf{8}$ were similar to those of $\mathbf{3}$ except for the signals due to the terminal glucose moiety. To investigate the binding sites of five monosaccharides, we employed a difference NOE. When the signals at $\delta 5.07,5.34$ (H-1 of each glucose), 5.81 (H-1 of apiose) and 6.05 (H-1 of rhamnose) were irradiated, NOEs were observed at $\delta 4.14(\mathrm{~d}, J=3 \mathrm{~Hz}$, H-3 of bayogenin), $4.10(\mathrm{t}, J=8 \mathrm{~Hz}, \mathrm{H}-2$ of glucose attached at C-3 of bayogenin), and 4.15 and 4.33 (H-3, $\mathrm{H}-2$ of ester-linked glucose), respectively. Consequently, the structure of polygalasaponin VIII was deduced as 3-O$[\beta$-D-glucopyranosyl $(1 \rightarrow 2)$ - $\beta$-D-glucopyranosyl $]$ bayogenin $28-O-\{\beta$-D-apiofuranosyl $(1 \rightarrow 3)-[\alpha-\mathrm{L}-$ rhamnopyranosyl $(1 \rightarrow 2)]-\beta$-D-glucopyranosyl $\}$ ester.

Polygalasaponin IX (9), $\mathrm{C}_{59} \mathrm{H}_{96} \mathrm{O}_{28}$, was similar to that of 7 except for a terminal xylose moiety in the ${ }^{1} \mathrm{H}$ - and ${ }^{13} \mathrm{C}-\mathrm{NMR}$ spectra. Acid hydrolysis liberated D-glucose, L-rhamnose and D-xylose. The sugar linkages were determined by the NOE method. When the signals at $\delta 5.07,5.33$ ( $\mathrm{H}-1$ of each glucose), 6.45 ( $\mathrm{H}-1$ of rhamnose) and 5.05 (H-1 of xylose) were irradiated, NOEs were observed at signals due to $\mathrm{H}-3$ of bayogenin, $\mathrm{H}-2$ of glucose attached at C-3 of bayogenin, $\mathrm{H}-2$ of ester-linked glucose and $\mathrm{H}-4$ of rhamnose, respectively. The structure of polygalasaponin IX was then determined to be $3-O-[\beta-\mathrm{D}-$ glucopyranosyl $(1 \rightarrow 2)$ - $\beta$-D-glucopyranosyl]bayogenin 28 $O$ - $\beta$-D-xylopyranosyl $(1 \rightarrow 4)$ - $\alpha$-L-rhamnopyranosyl $(1 \rightarrow 2)$ $\beta$-D-glucopyranosyl ester.

Polygalasaponin X (10) yielded D-glucose, D-apiose, L-rhamnose and D-xylose on acid hydrolysis. In the NMR spectra, 10 showed six anomeric proton and carbon signals at $\delta 5.05(\mathrm{~d}, J=7 \mathrm{~Hz}), 5.08(\mathrm{~d}, J=8 \mathrm{~Hz}), 5.33(\mathrm{~d}, J=8 \mathrm{~Hz})$, $5.80(\mathrm{~d}, J=3 \mathrm{~Hz}), 5.98(\mathrm{br} \mathrm{s}), 6.19(\mathrm{~d}, J=7 \mathrm{~Hz}) ; 94.2$, $101.5,103.0,105.8,107.4,111.0$. Glycosylation shifts at $\mathrm{C}-2(-1.2 \mathrm{ppm}), \mathrm{C}-3(+10.0 \mathrm{ppm})$ and C-28 (-3.9 ppm) of the aglycone suggested that $\mathbf{1 0}$ was a 3,28-bisdesmoside of bayogenin, since the anomeric proton signal ( $\delta 6.19$, $\mathrm{d}, J=7 \mathrm{~Hz})$ and carbon signal $(\delta 94.2)$ due to glucose suggested that this glucose is attached at C-28 of bayogenin. The binding sites of five other monosaccharides were determined by the NOE method. When the signals at $\delta 5.08,5.33(\mathrm{H}-1$ of each glucose $), 5.98(\mathrm{H}-1$ of rhamnose), 5.80 (H-1 of apiose) and 5.05 (H-1 of xylose) were irradiated, NOEs were observed at signals due to $\mathrm{H}-3$ of the aglycone, $\mathrm{H}-2$ of glucose bound at $\mathrm{C}-3$ of the aglycone, $\mathrm{H}-2$ and $\mathrm{H}-3$ of ester-linked glucose and $\mathrm{H}-4$ of rhamnose, respectively. From these data, the structure of polygalasaponin $\mathrm{X}$ was elucidated as $3-O-[\beta$-D-glucopyranosyl $(1 \rightarrow 2)-\beta$-D-glucopyranosyl $]$ bayogenin $28-O-\{\beta$-Dxylopyranosyl $(1 \rightarrow 4)$ - $\alpha$-L-rhamnopyranosyl $(1 \rightarrow 2)-[\beta$-Dapiofuranosyl $(1 \rightarrow 3)]$ - $\beta$-D-glucopyranosyl $\}$ ester.

The anomeric configurations of glucose and xylose in these saponins were determined to all be $\beta$ from the $J$ value of the anomeric proton signals, and those of rhamnose and apiose were determined to be $\alpha$ and $\beta$, respectively, by comparison of the ${ }^{13} \mathrm{C}-\mathrm{NMR}$ data of $\mathrm{C}-3$ and C-5 of rhamnose ${ }^{6)}$ and $\mathrm{C}-1$ and $\mathrm{C}-2$ of apiose. ${ }^{7)}$

\footnotetext{
Experimental

General Procedure ${ }^{1} \mathrm{H}$ - and ${ }^{13} \mathrm{C}-\mathrm{NMR}$ spectra were obtained with a JEOL GSX-500 FT NMR at $35^{\circ} \mathrm{C}$ and chemical shifts were given in ppm with tetramethylsilane as an internal stantard. FAB-MS was recorded on a JEOL JMS-SX102 mass-spectrometer. Optical rotations were measured with a JASCO DIP-360 digital polarimeter. Gas chro-
} 
TABLE III. ${ }^{13}$ C-NMR Spectral Data of Sugar Moiety of Compounds $1-12$ in Pyridine- $d_{5}$

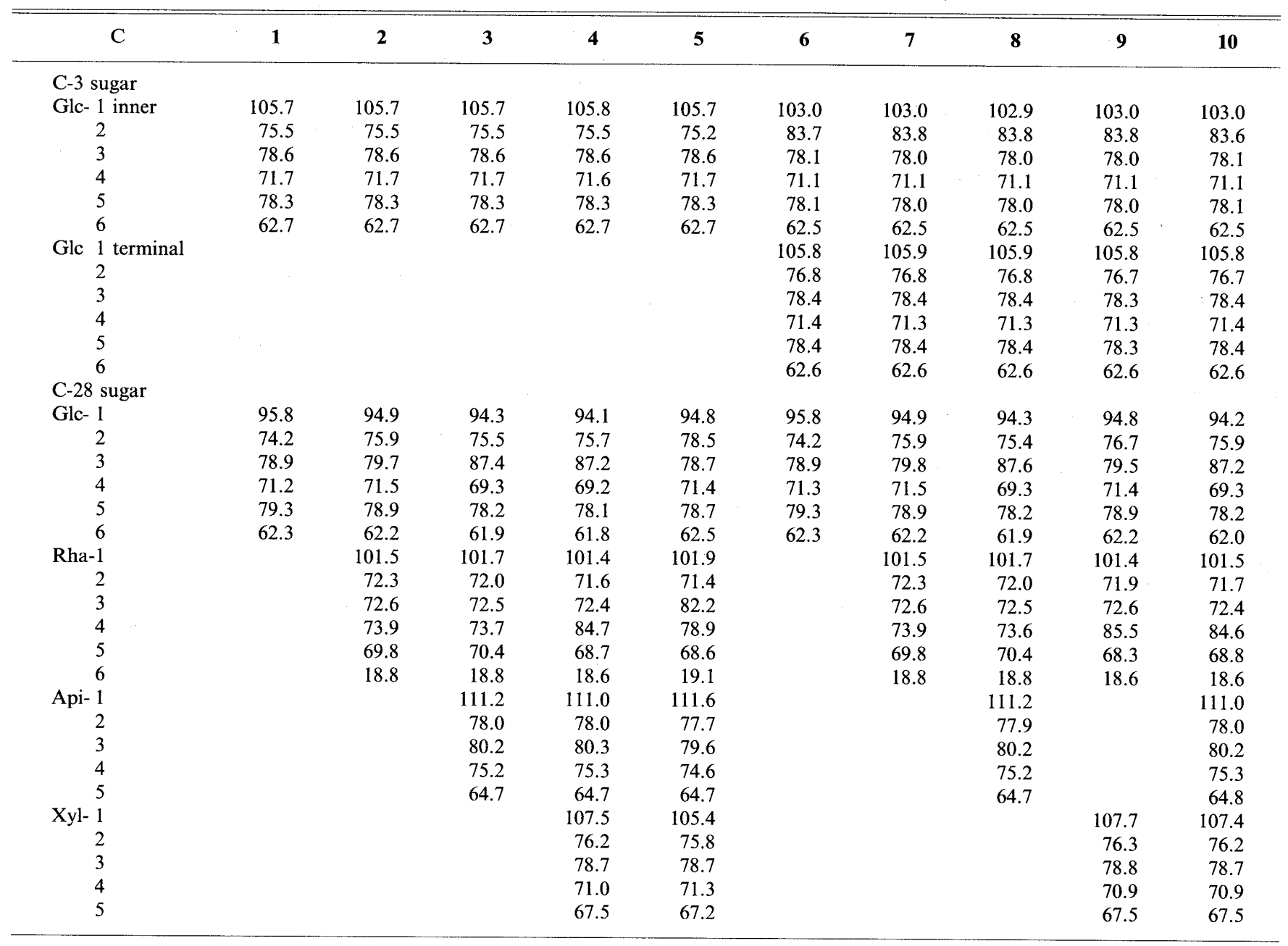

Recorded at $125.65 \mathrm{MHz}$ at $35^{\circ} \mathrm{C}$.

matography (GC) was run on a Hitachi G-3000 gas chromatograph. Preparative and semi-preparative HPLC was carried out on a column of Develosil Lop-ODS $(5 \mathrm{~cm} \times 50 \mathrm{~cm})$ and YMC D-ODS-7 $(2 \mathrm{~cm} \times 25 \mathrm{~cm})$ or Develosil PhA-7 $(2 \mathrm{~cm} \times 25 \mathrm{~cm})$, respectively.

Extraction and Isolation Polygala japonica Houtr. was collected in Jiangxi, China in May 1993. The aerial part (dried, $5 \mathrm{~kg}$ ) of $P$. japonica HouTT. was extracted twice with $70 \%$ aqueous EtOH. The extract was passed through a porous polymer gel Mitsubishi Diaion HP-20 column after evaporation of EtOH. After the content of the column was washed with water, the adsorbed materials were eluted with $50 \%$ aqueous methanol and methanol, successively. The methanol eluate $(80 \mathrm{~g})$ was chromatographed on a silica gel with $\mathrm{CHCl}_{3}-\mathrm{MeOH}-\mathrm{H}_{2} \mathrm{O}(85: 14: 1)$, increasing a portion of $\mathrm{MeOH}$ to give 19 fractions (frs. $\mathrm{A}-\mathrm{S}$ ). From frs. $B, E$ and $O$, compounds $1-12$ were isolated by preparative and semi-preparative HPLC. 1 (258 mg), 2 (105 mg), 3 (30 mg), 4 (36 mg), 5 (36 mg), 6 (329 mg), 7 (150 mg), 8 (135 mg), 9 (78 mg), 10 (48 mg), 11 (486 mg), 12 (831 mg).

Polygalasaponin I (1): Amorphous powder, $[\alpha]_{\mathrm{D}}^{27}+25.7^{\circ}(c=1.07$, $\mathrm{MeOH}$ ). Anal. Calcd for $\mathrm{C}_{42} \mathrm{H}_{68} \mathrm{O}_{15} \cdot 5 / 2 \mathrm{H}_{2} \mathrm{O}$ : C, 58.79; $\mathrm{H}, 8.58$. Found: C, 58.62; H, 8.47. FAB-MS $m / z: 835[\mathrm{M}+\mathrm{Na}]^{+}$. ${ }^{1} \mathrm{H}-\mathrm{NMR}$ : shown in Tables I and II. ${ }^{13} \mathrm{C}-\mathrm{NMR} \delta$ : aglycone moiety: 44.2 (C-1), 70.6 (C-2), 83.1 (C-3), 42.4 (C-4), 47.8 (C-5), 18.1 (C-6), 32.6 (C-7), 40.1 (C-8), 48.6 (C-9), 37.0 (C-10), 24.1 (C-11), 123.2 (C-12), 144.2 (C-13), 42.8 (C-14), 28.3 (C-15), 23.5 (C-16), 47.1 (C-17), 41.8 (C-18), 46.2 (C-19), 30.8 (C-20), 34.1 (C-21), 33.0 (C-22), 65.7 (C-23), 15.1 (C-24), 17.4 (C-25), 17.7 (C-26), 26.2 (C-27), 176.5 (C-28), 33.2 (C-29), 23.7 (C-30). ${ }^{13} \mathrm{C}-\mathrm{NMR}$ data of aglycone moiety of $2-12$ are nearly the same as this data; sugar moiety: shown in Table III.

Polygalasaponin II (2): Amorphous powder, $[\alpha]_{\mathrm{D}}^{27} 0^{\circ} \quad(c=0.85$, $\mathrm{MeOH}$. Anal. Calcd for $\mathrm{C}_{48} \mathrm{H}_{78} \mathrm{O}_{19} \cdot 4 \mathrm{H}_{2} \mathrm{O}: \mathrm{C}, 55.91 ; \mathrm{H}, 8.41$. Found:
C, 56.02; H, 8.50. FAB-MS $m / z: 982[\mathrm{M}+\mathrm{Na}]^{+} .{ }^{1} \mathrm{H}-\mathrm{NMR}$ : shown in Tables I and II. ${ }^{13} \mathrm{C}-\mathrm{NMR}$ sugar moiety: shown in Table III.

Polygalasaponin III (3): Amorphous powder, $[\alpha]_{\mathrm{D}}^{27}-11.5^{\circ}(c=0.39$, MeOH). Anal. Calcd for $\mathrm{C}_{53} \mathrm{H}_{86} \mathrm{O}_{23} \cdot 3 \mathrm{H}_{2} \mathrm{O}: \mathrm{C}, 55.58 ; \mathrm{H}, 8.10$. Found: $\mathrm{C}, 55.71 ; \mathrm{H}, 8.34$. FAB-MS $m / z: 1114[\mathrm{M}+\mathrm{Na}]^{+}$. ${ }^{1} \mathrm{H}-\mathrm{NMR}$ : shown in Tables I and II. ${ }^{13} \mathrm{C}-\mathrm{NMR}$ sugar moiety: shown in Table III.

Polygalasaponin IV (4): Amorphous powder, $[\alpha]_{\mathrm{D}}^{27}-10.8^{\circ}(c=0.51$, $\mathrm{MeOH}$ ). Anal. Calcd for $\mathrm{C}_{58} \mathrm{H}_{94} \mathrm{O}_{27} \cdot 11 / 2 \mathrm{H}_{2} \mathrm{O}: \mathrm{C}, 52.72 ; \mathrm{H}, 7.93$. Found: C, 52.78; H, 8.00. FAB-MS $m / z: 1246[\mathrm{M}+\mathrm{Na}]^{+} .{ }^{1} \mathrm{H}-\mathrm{NMR}$ : shown in Tables I and II. ${ }^{13} \mathrm{C}-\mathrm{NMR}$ sugar moiety: shown in Table III.

Polygalasaponin V (5): Amorphous powder, $[\alpha]_{\mathrm{D}}^{27}-16.7^{\circ}(c=0.48$, MeOH). Anal. Calcd for $\mathrm{C}_{58} \mathrm{H}_{94} \mathrm{O}_{27} \cdot 5 \mathrm{H}_{2} \mathrm{O}: \mathrm{C}, 53.04 ; \mathrm{H}, 7.98$. Found: $\mathrm{C}$, 53.12; $\mathrm{H}$, 7.85. FAB-MS $m / z: 1246[\mathrm{M}+\mathrm{Na}]^{+}$. ${ }^{1} \mathrm{H}-\mathrm{NMR}$ : shown in Tables I and II. ${ }^{13} \mathrm{C}-\mathrm{NMR}$ sugar moiety: shown in Table III.

Polygalasaponin VI (6): Amorphous powder, $[\alpha]_{\mathrm{D}}^{27}+28.3^{\circ}(c=1.15$, $\mathrm{MeOH}$ ). Anal. Calcd for $\mathrm{C}_{48} \mathrm{H}_{78} \mathrm{O}_{20} \cdot \mathrm{H}_{2} \mathrm{O}$ : C, 58.05; H, 8.12. Found: C, 57.85; H, 8.23. FAB-MS $m / z$ : $997[\mathrm{M}+\mathrm{Na}]^{+}$. ${ }^{1} \mathrm{H}-\mathrm{NMR}$ : shown in Tables I and II. ${ }^{13} \mathrm{C}-\mathrm{NMR}$ sugar moiety: shown in Table III.

Polygalasaponin VII (7): Amorphous powder, $[\alpha]_{\mathrm{D}}^{27}+1.2^{\circ}(c=0.84$, MeOH). Anal. Calcd for $\mathrm{C}_{54} \mathrm{H}_{88} \mathrm{O}_{24} \cdot \mathrm{H}_{2} \mathrm{O}$ : C, 56.93; H, 7.96. Found: $\mathrm{C}, 57.13 ; \mathrm{H}, 7.93$. FAB-MS $m / z$ : $1144[\mathrm{M}+\mathrm{Na}]^{+} .{ }^{1} \mathrm{H}-\mathrm{NMR}$ : shown in Tables I and II. ${ }^{13} \mathrm{C}$-NMR sugar moiety: shown in Table III.

Polygalasaponin VIII (8): Amorphous powder, $[\alpha]_{\mathrm{D}}^{25}+10.6^{\circ}$ ( $c=1.04$, pyridine). Anal. Calcd for $\mathrm{C}_{59} \mathrm{H}_{96} \mathrm{O}_{28} \cdot 9 / 2 \mathrm{H}_{2} \mathrm{O}: \mathrm{C}, 53.10 ; \mathrm{H}$, 7.93. Found: C, 53.20; H, 8.12. FAB-MS $m / z: 1276[\mathrm{M}+\mathrm{Na}]^{+}$. ${ }^{1} \mathrm{H}$-NMR: shown in Tables I and II. ${ }^{13} \mathrm{C}-\mathrm{NMR}$ sugar moiety: shown in Table III.

Polygalasaponin IX (9): Amorphous powder, $[\alpha]_{\mathrm{D}}^{27}-1.3^{\circ}(c=0.38$, $\mathrm{MeOH}$ ). Anal. Calcd for $\mathrm{C}_{59} \mathrm{H}_{96} \mathrm{O}_{28} \cdot 7 / 2 \mathrm{H}_{2} \mathrm{O}: \mathrm{C}, 53.83 ; \mathrm{H}, 7.89$. Found: C, 53.76; H, 8.14. FAB-MS $m / z$ : $1276[\mathrm{M}+\mathrm{Na}]^{+}$. ${ }^{1} \mathrm{H}-\mathrm{NMR}$ : shown in 
Tables I and II. ${ }^{13} \mathrm{C}$-NMR sugar moiety: shown in Table III.

Polygalasaponin X (10): Amorphous powder, $[\alpha]_{\mathrm{D}}^{25}+17.2^{\circ}(c=0.32$, pyridine). Anal. Calcd for $\mathrm{C}_{64} \mathrm{H}_{104} \mathrm{O}_{32} \cdot 11 / 2 \mathrm{H}_{2} \mathrm{O}: \mathrm{C}, 51.78 ; \mathrm{H}, 7.81$. Found: C, $51.75 ; \mathrm{H}, 7.77$. FAB-MS $m / z: 1408[\mathrm{M}+\mathrm{Na}]^{+}$. ${ }^{1} \mathrm{H}-\mathrm{NMR}$ : shown in Tables I and II. ${ }^{13} \mathrm{C}$-NMR sugar moiety: shown in Table III.

Acid Hydrolysis of Bayogenin-3-O-glucopyranoside (11) Compound $11(100 \mathrm{mg})$ was refluxed with dioxane $(8 \mathrm{ml})$ and $5 \% \mathrm{H}_{2} \mathrm{SO}_{4}(2 \mathrm{ml})$ for $2 \mathrm{~h}$. The reaction mixture was diluted with $\mathrm{H}_{2} \mathrm{O}$ and extracted with ether The ether layer was evaporated to dryness. The residue was recrystallized from $\mathrm{MeOH}-\mathrm{CHCl}_{3}$ to give bayogenin $(\mathbf{1 3})(12 \mathrm{mg})$ as colorless needles, mp $320-322^{\circ} \mathrm{C}(\mathrm{dec}),.[\alpha]_{\mathrm{D}}^{27}+126.9^{\circ}(c=0.67$, pyridine) that was identified by comparison of ${ }^{1} \mathrm{H}$ - and ${ }^{13} \mathrm{C}$-NMR data with reported data. ${ }^{5)}$

Acid Hydrolysis of Saponins 1-12 Each saponin $(2 \mathrm{mg})$ was heated at $100{ }^{\circ} \mathrm{C}$ with dioxane $(0.05 \mathrm{ml})$ and $5 \% \mathrm{H}_{2} \mathrm{SO}_{4}(0.05 \mathrm{ml})$ for $1 \mathrm{~h}$. After dilution with water, the reaction mixture was extracted with ethyl acetate twice and the water layer was passed through an Amberlite IRA-60E column. The water eluate was concentrated and the residue was treated with D-cysteine ${ }^{8)}(0.05 \mathrm{mg})$ in water $(0.03 \mathrm{ml})$ and pyridine $(0.015 \mathrm{ml})$ at $60^{\circ} \mathrm{C}$ for $1 \mathrm{~h}$ with stirring. After the solution was evaporated and the reaction mixture was dried, pyridine $(0.015 \mathrm{ml})$, hexamethyldisilazane $(0.015 \mathrm{ml})$ and trimethylsilylchloride $(0.015 \mathrm{ml})$ were added to the residue. The reaction mixture was heated at $60^{\circ} \mathrm{C}$ for $30 \mathrm{~min}$. The supernatant was applied to GC. The ethyl acetate layer was concentrated and subjected to HPLC to reveal a peak due to bayogenin from every saponin. GC conditions: column, Supelco $\mathrm{SPB}^{\mathrm{TM}}-1,0.25 \mathrm{~mm} \times 27 \mathrm{~m}$; column temperature, $230^{\circ} \mathrm{C}$; carrier gas, $\mathrm{N}_{2} ; t_{\mathrm{R}}$ : D-apiose $10.3 \mathrm{~min}, \mathrm{~L}$-apiose $9.7 \mathrm{~min},{ }^{9)}$ D-xylose $10.7 \mathrm{~min}$, L-xylose $9.7 \mathrm{~min}$, L-rhamnose $12.2 \mathrm{~min}$, D-rhamnose $12.0 \mathrm{~min},{ }^{9)}$ D-glucose $17.8 \mathrm{~min}$, L-glucose $17.2 \mathrm{~min}$. D-
Glucose was detected from 1-12. L-Rhamnose was detected from $2-5$, 7-10. D-Xylose was detected from 4, 5,9 and 10. D-Apiose was detected from $3,4,5,8$ and 10. HPLC conditions: column, Develosil R-ODS-7, $4.6 \mathrm{~mm} \times 25 \mathrm{~cm}$; solvent, $\mathrm{MeCN}-\mathrm{H}_{2} \mathrm{O}(55: 45)$; flow rate, $1.0 \mathrm{ml} / \mathrm{min} ; \mathrm{UV}$ $205 \mathrm{~nm} ; t_{\mathrm{R}}$, bayogenin $9.2 \mathrm{~min}$.

Acknowledgments We thank the staff of the Central Analytical Laboratory of this university for elemental analyses and the measurement of MS.

\section{References and Notes}

1) Chiang Su New Medicinal College, "Dictionary of Chinese Crude Drug," Shanghai Scientific Technologic Publisher, Shanghai, 1977, p.757.

2) Z. P. Fang, G. J. Yin, Acta Botanica Sinica, 28, 196 (1986).

3) Z. P. Fang, G. J. Yin, Acta Botanica Sinica, 31, 708 (1989).

4) A. Marston, F. Gafner, S. F. Dossaji, K. Hostettmann, Phytochemistry, 27, 1325 (1988).

5) T. Fujioka, M. Iwamoto, Y. Iwase, S. Hachiyama, H. Okabe, T. Yamauchi, K. Mihashi, Chem. Pharm. Bull., 37, 2355 (1989).

6) R. Kasai, M. Okihara, J. Asakawa, K. Mizutani, O. Tanaka, Tetrahedron, 35, 1427 (1979)

7) I. Kitagawa, M. Sakagami, M. Hashiuchi, J. L. Zhou, M. Yoshikawa, J. Ren, Chem. Pharm. Bull., 37, 551 (1989).

8) S. Hara, H. Okabe, K. Mihashi, Chem. Pharm. Bull., 34, 1843 (1986).

9) The $t_{\mathrm{R}}$ for L-apiose and D-rhamnose were obtained from their enantiomer (D-apiose + L-cysteine and L-rhamnose + L-cysteine, respectively). 